\title{
CORRECTION
}

Open Access

\section{Correction to: Is old stuff back? A fatal case of ethyl chloride sniffing}

Jennifer P. Pascali ${ }^{1 *}$, Paolo Fais $^{2}$, Guido Viel ${ }^{3}$, Giovanni Cecchetto ${ }^{3}$ and Massimo Montisci ${ }^{3}$

\section{Correction to: Egypt J Forensic Sci (2019) 9:29 \\ https://doi.org/10.1186/s41935-019-0136-4}

After the publication of this article (Pascali et al., 2019) it was brought to the authors' attention that the appropriate consent statement was not included in the manuscript. Written informed consent for publication could not be obtained from the deceased individual's next-of-kin despite all reasonable attempts. Every effort has been made to protect the identity of the individual.

\section{Author details}

${ }^{1}$ Forensic Toxicology Division, Department of Health Sciences, University of Florence, Largo Brambilla 3, 50134 Florence, Italy. ${ }^{2}$ Department of Medical and Surgical Sciences, DIMEC, University of Bologna, 40126 Bologna, Italy. ${ }^{3}$ Legal Medicine and Toxicology, University-Hospital of Padova, Via Falloppio, 50, 35121 Padova, Italy.

Published online: 25 July 2020

\section{Reference}

Pascali JP, Fais P, Viel G, Cecchetto G, Montisci M (2019) Is old stuff back? A fatal

case of ethyl chloride sniffing. Egypt J Forensic Sci 9:29. https://doi.org/10.

1186/s41935-019-0136-4

The original article can be found online at https://doi.org/10.1186/s41935019-0136-4.

* Correspondence: jennifer.pascali@gmail.com

The original article can be found online at https://doi.org/10.1186/s41935019-0136-4

${ }^{1}$ Forensic Toxicology Division, Department of Health Sciences, University of Florence, Largo Brambilla 3, 50134 Florence, Italy

Full list of author information is available at the end of the article

(c) The Author(s). 2020 Open Access This article is licensed under a Creative Commons Attribution 4.0 International License, which permits use, sharing, adaptation, distribution and reproduction in any medium or format, as long as you give appropriate credit to the original author(s) and the source, provide a link to the Creative Commons licence, and indicate if changes were made. The images or other third party material in this article are included in the article's Creative Commons licence, unless indicated otherwise in a credit line to the material. If material is not included in the article's Creative Commons licence and your intended use is not permitted by statutory regulation or exceeds the permitted use, you will need to obtain permission directly from the copyright holder. To view a copy of this licence, visit http://creativecommons.org/licenses/by/4.0/. 